This item was submitted to Loughborough's Research Repository by the author.

Items in Figshare are protected by copyright, with all rights reserved, unless otherwise indicated.

\title{
Contested states and the politics of sport: the case of Kosovo - division, development, and recognition
}

PLEASE CITE THE PUBLISHED VERSION

http://dx.doi.org/10.1080/19406940.2016.1217251

\section{PUBLISHER}

(c) Taylor \& Francis

\section{VERSION}

AM (Accepted Manuscript)

\section{PUBLISHER STATEMENT}

This work is made available according to the conditions of the Creative Commons Attribution-NonCommercialNoDerivatives 4.0 International (CC BY-NC-ND 4.0) licence. Full details of this licence are available at: https://creativecommons.org/licenses/by-nc-nd/4.0/

\section{LICENCE}

CC BY-NC-ND 4.0

\section{REPOSITORY RECORD}

Giulianotti, Richard, Holly Collison, Simon Darnell, and P. David Howe. 2019. "Contested States and the Politics of Sport: The Case of Kosovo - Division, Development, and Recognition”. figshare. https://hdl.handle.net/2134/24202. 


\title{
Contested States and the Politics of Sport:
}

\section{The Case of Kosovo - Division, Development, and Recognition ${ }^{1}$}

\author{
Richard Giulianotti, Holly Collison,
}

\section{Simon Darnell and David Howe}

\section{Introduction}

On 9 December 2014, the Western Balkan state of Kosovo was admitted as a full member nation into the International Olympic Committee (IOC). This was a highly significant day for sport, politics and society in Kosovo, in the long national struggle to secure international recognition, coming six years after declaring independence from Serbia, and fifteen years after the end of the Kosovo War between Serbian-led Yugoslav forces and the Kosovo Liberation Army. Five months after Olympic entry, the IOC President Thomas Bach paid an official visit to Kosovo amidst great political and public fanfare. Reflecting the role of sport in securing international recognition for Kosovo, some Kosovar sports officials described Bach as the 'most important visitor' to the young nation-state since the end of the civil war. ${ }^{2}$ Kosovo’s athletes were now free to compete in Olympic competition, including the 2016 Rio Olympics, before audiences of world leaders and global television viewers, leaving, at that

\footnotetext{
${ }^{1}$ The research for this paper was financed by the UK Economic and Social Research Council (award number ES/L002191/1).

${ }^{2}$ From an interview with Kosovo sport officials, April 2015.
} 
point, European and world football governing bodies UEFA and FIFA as the last major international sport governing bodies to grant recognition.

In this paper, we provide the first detailed analysis of the politics of sport in the small, contested state of Kosovo. We consider, for example, how particular political interests have utilized sport as a pragmatic diplomatic resource, such as to pursue full international recognition for Kosovo as an autonomous and legitimate nation-state. Our discussion also examines how the political and societal challenges that confront post-war Kosovo - as one of Europe’s poorest, youngest, most divided, and least integrated nations - have deep implications for sport. As we explain, the sport-politics interface within Kosovo is played out specifically through issues concerning development and reconstruction, international recognition, ethno-national divisions, and cross-community peace-building. For clarification, we view Kosovo as a contested, small state in the sense that, first, as we shall see, its independent status is contested or not recognized by a substantial minority of nation-states across the world; and second, as we detail, Kosovo corresponds in important and complex ways to the literature on 'small states'. This status as a contested, small state has direct ramifications for sport in Kosovo.

We organize our discussion of these issues into three main parts. First, we begin by setting out briefly our broad analytical approach, with respect to our selective usage of key theories from international relations, before examining the crucial wider contexts for sport in Kosovo, with regard to society, history and politics, and its 'small state' status with respect to recent relevant literature. Second, we discuss the main political features of sport in Kosovo, highlighting issues of development, recognition, and conflicts and divisions between the Albanian and Serbian communities in particular. This leads on to our third section, which addresses the cultural politics of sport in Kosovo with reference to issues of national and transnational identification, symbolic conflicts, and the role of the sport for development and 
peace (SDP) sector in building cross-community ties. While the broad focus of section two is on 'top-down', governmental politics, involving particularly the Kosovo state, sport federations, and intergovernmental organizations, section three is focused more on 'bottomup', social and cultural politics at the level of civil society, with reference for example to nongovernmental organizations.

Our paper draws primarily on qualitative research undertaken in Kosovo in 2015 and early 2016 as part of a larger project. Two research visits were made to Kosovo, generating 68 interviews with officials from national government (6 interviews), sport federations (8), NGOs (14) and intergovernmental organizations (6), as well as with sport politicians (2), sport coaches (5), volunteers (7), and participants (14), journalists (3), and academics (3). Interviews were conducted and transcribed with support from translators working in Albanian, Serbian and Turkish languages. Access to these stakeholders was obtained through initial key contacts in Kosovo, notably, a local sport coach, academics who had worked there in the past, and NGO officials. Further interviews were undertaken with officials by telephone and Skype. ${ }^{3}$ The research also featured fieldwork visits to sport events (such as national-level men's football and women's basketball fixtures), and twelve sport activities in different parts of Kosovo that were staged by international, national, and local NGOs working in the sport for development and peace (SDP) sector.

\section{Kosovo: A Contextual Portrait}

\section{Society, History and Politics}

In this section, to establish the context for the politics of sport, we briefly examine Kosovo's wider society, history and politics before moving to consider its status as a 'small state'. We

\footnotetext{
${ }^{3}$ Pseudonyms are used throughout this paper when reference is made to named interviewees.
} 
situate our overall analysis within international relations theories, more specifically within the selective usage and integration of four main perspectives: realist, liberal, constructivist, and critical. Our overall emphasis is on a mix of critical and constructivist approaches. While this synthesis may appear excessively diverse for some scholars, we consider this to be essential in order to register conceptually both the complexity of Kosovo’s national and international position, and the depth of our data, particularly the rich insights of our interviewees. In our view, an alternative, theory-led methodology - in which one or two preidentified master theories are imposed on the empirical content - would be unduly restrictive for explaining the context and data.

Turning to the broad explanatory benefits of these theories, we begin by noting that, first, realist theory enables us to examine the realpolitik of 'power politics', particularly how states may threaten or seek to harm other states in pursuing their own interests or hegemonic projects (Gilpin 1987; Wight 1946). Second, liberal theory registers how institutions such as the United Nations, European Union and Council of Europe have come to be understood in international politics as 'foundations of social progress', as illustrated by their military, economic and development interventions; liberal theory also identifies growing levels of legalism and moralism in international affairs, for example through the proliferation of human rights treaties and non-governmental organizations (Keohane 2012: 126, 130). Third, constructivist theory helps to account for: how international politics are socially constructed by political actors; the importance of political norms, beliefs and identities; the normative advocacy roles of transnational institutions such as United Nations agencies; and, the greater influence of non-state actors (such as NGOs) on states and wider societies (Barnett \& Finnemore 2004; Keck and Sikkink 1998). Fourth, through critical theory we recognize the political-economic roots of power relations and divisions between states, reflected in the global rise of neoliberalism; the growing significance of non-state actors and greater 
complexity of international politics; the struggle for political recognition by diverse marginalized identities; and, the normative focus of diverse political forces on human emancipation and universal principles centred on democracy, dialogue, human rights and social justice (Linklater 2007; Roach 2007). These theories - particularly critical and constructivist accounts - help to explain sport, politics and society within Kosovo.

Turning to discuss its core geo-political and demographic features, to summarize, Kosovo is a land-locked, disputed 'small state' and former province of Yugoslavia, located in the Western Balkans (see Maps 1 and 2). It has a tight geographical area of around 10,900 square kilometres (around the same size as Jamaica), a small population of some 1,850,000 inhabitants, and an estimated GDP (2014) of around US\$7-7.4 billion (similar to Kyrgyzstan and Guinea). ${ }^{4}$ Having declared independence from Serbia in 2008, by end of 2015, Kosovo was recognized by 108 of 193 United Nations member states, including most of Europe and North America, but not Serbia, Russia (which holds veto powers on the UN Security Council), other nations such as China, Spain, and Greece, and much of Central and South America. This marginality within international society, particularly in lacking European Union and United Nations membership, has meant that Kosovo has been substantially reliant on political support and economic aid from major Western powers. In turn, the Kosovo state and public institutions have sought pragmatic and creative solutions to operating within international society, such as through securing membership of international sport federations like the IOC. ${ }^{5}$ These efforts did lead to major successes in May 2016: first, when Kosovo was admitted into UEFA and FIFA, opening the way for participation in qualifiers for the 2018 World Cup finals in Russia; and second, when the European Commission recommended the lifting of visa requirements on Kosovo citizens for short-stay visits in the Schengen area.

\footnotetext{
${ }^{4}$ See http://www.imf.org; http://databank.worldbank.org/data/download/GDP.pdf.

${ }^{5}$ In addition, at civil society level, the leading national magazine Kosovo 2.0 (2015) initiated a 'Kosovo Wants to Play' campaign to pursue such recognition.
} 
In terms of its core demography, Kosovo’s inhabitants are largely mono-national, young, poor, and diasporic. The population is roughly 88-92\% Albanian, 4-8\% Serbian, and 4-6\% 'other' (primarily Bosniaks, Turks, Roma, Ashkali and Egyptians). Albanian and Serbian are official languages, and both are conventionally used to name regions and municipalities; other recognized languages include Turkish, Bosnian, Romani and Gorani. Most areas have large majority Albanian populations, however some have Serbian majorities, notably the North Kosovo region (including North Mitrovica), Gracanica and Ranilug, while others, such as the town of Strpce, have substantial Serbian minorities. ${ }^{6}$ In 2015 at least half of Kosovo’s population was aged 25 or younger. ${ }^{7}$ GDP per capita was estimated at only $€ 2,700$ in 2014, with around one-third of inhabitants living in poverty, and one-eighth in extreme poverty. ${ }^{8}$ While growth has been around 3-6\% annually through 2005-2014, average salaries were among Europe’s lowest, unemployment rates were 30\%-50\%, and youth unemployment at 55-75\%. ${ }^{9}$ Consequently, an estimated 700,000-800,000 Kosovars live and work in Western Europe, primarily Switzerland and Germany; tens of thousands of Kosovo’s inhabitants migrated west in late 2014 and 2015 (Reuters, 4 February 2015; Guardian, 17 February 2015). Remittances from this Kosovar diaspora have helped sustain the national economy, accounting for at least $15-18 \%$ of GDP since $1995 .^{10}$

Kosovo has a very long history of ethno-national and territorial conflicts, mostly rooted in the realist 'power politics' of national and nation-state divisions. Though portrayed by Serbian nationalists as 'the cradle of the Serbian nation' since the 12th-14th centuries, Albanians have

\footnotetext{
${ }^{6}$ We have taken the step of using more familiar English names for locations in Kosovo.

${ }^{7}$ See http://www.bbc.co.uk/news/world-europe-31967471;

http://www.eurasia.undp.org/content/rbec/en/home/ourwork/hiv_aids/successstories/post-2015--the-voice-ofyoung-kosovo.html.

${ }^{8} \mathrm{http}: / / \mathrm{www} . w o r l d b a n k . o r g / e n / c o u n t r y / k o s o v o /$ overview

${ }^{9}$ See http://hdr.undp.org/sites/default/files/khdr2014english.pdf;

http://data.worldbank.org/indicator/NY.GDP.MKTP.KD.ZG; http://www.rtklive.com/en/?id=3\&r=1748. Average monthly public sector wages are estimated at $€ 365$, with the private sector understood to offer much lower wages.

${ }^{10}$ See http://data.worldbank.org/indicator/BX.TRF.PWKR.DT.GD.ZS
} 
been the majority people in Kosovo since at least the early $18^{\text {th }}$ century (Heraclides 1997: 318; Judah 2008: 20-1). Post-1945, Kosovo became an autonomous province of Yugoslavia as part of President Tito’s strategy of distributing and balancing powers across different national interests. After Tito’s death, Kosovo became a key focus for rising Serbian nationalism and a critical site for the Yugoslav civil war in the 1990s (Judah 2000: 33). The subsequent Kosovo War of 1998-99 between Serbian Yugoslav forces and the Albanian Kosovo Liberation Army led to an estimated 13,500 deaths, and 90\% of Albanians being displaced, including 850,000 refugees who fled abroad (Judah 2008: 91; Petersen 2011: 156). ${ }^{11}$ NATO intervened in March 1999, bombing Serbia for 78 days until Serbian leader Slobodan Milosevic withdrew his forces from Kosovo; the UN Security Council passed Resolution 1244, and Kosovo came under the auspices of a United Nations Interim Administration Mission (UNMIK) until 2008. Albanian refugees returned, most Serbs left, though some remained within or returned into ethnic enclaves.

Following the destruction of homes, communities, businesses, many essential utilities, and the collapse of public institutions, post-conflict Kosovo required the systematic reconstruction and development of its infrastructure and essential public services, along with its polity, economy, and civil society. A critical role in financing and undertaking such reconstruction was played by the liberal-democratic 'international community’: in other words, the United States, Western European nations, United Nations agencies (notably UNMIK), European Union agencies (notably through EULEX ${ }^{12}$ ), Council of Europe, and numerous Western NGOs. In turn, Kosovo, and in particular the capital, Pristina, hosted tens of thousands of mainly Western European and North American 'internationals', as they came

\footnotetext{
${ }^{11}$ See http://www.kosovomemorybook.org/wpcontent/uploads/2015/02/Expert_Evaluation_of_Kosovo_Memory_Book_Database_Prishtina_04_02_2015.pdf; http://www.hrw.org/legacy/campaigns/kosovo98/timeline.shtml.

${ }_{12}$ The European Union Rule of Law Mission was established in Kosovo, providing in particular policing and judicial support, though with relatively limited impact in the Serb north (Visoka \& Bolton 2011).
} 
to be known to local people, who were working for these diverse Western agencies. Since the war, Kosovo’s Albanians have been strongly pro-American and pro-British, as registered by public buildings and hotels displaying these national symbols, murals celebrating NATO, and a statue of Bill Clinton unveiled in central Pristina. Yet, as Faton, a national NGO official put it to us, Kosovo was 'a ghetto in Europe', outside the EU and the United Nations, long unrecognized by UEFA and FIFA, and with its citizens requiring visas for travel into EU states. $^{13}$

Rejecting Kosovo's independence, Serbia has instead backed 'parallel state structures' for Serbian-speaking inhabitants of Kosovo, particularly the northern part of the country, for example by paying higher salaries to public-sector employees working with Serbians. ${ }^{14}$ Rejection of Kosovo's independence is most evident in the Serbian enclave of North Kosovo, where Serbian institutions, currency, language and symbols dominate entirely. Yet, in realist terms, Serbia’s policy of systematically undermining of Kosovo’s autonomy may be later traded to pursue a greater goal: both Serbia and Kosovo have aspirations to join the European Union (EU), with membership likely to require formal reciprocal recognition (cf. KerLindsay 2012: 126). The EU has sustained such aspirations through a 'neo-functionalist' peace-building strategy based on incremental advances, leading Kosovo and Serbia to sign the 2013 'Brussels Agreement', to normalize relations and facilitate some forms of integration (Visoka \& Doyle 2015). These and other EU-brokered agreements have met with substantial protests and demonstrations by both sides, including tear-gas attacks by Albanian opposition MPs in the Kosovo parliament (The Economist, 3 August 2013; Guardian, 23 October 2015). Other major problems within Kosovo’s state and society centre on acute forms of social marginalization (notably experienced on gender lines by women, and on

\footnotetext{
${ }^{13}$ This interview was held before the EC announcement in May 2016 of visa liberalisation.

${ }^{14}$ Following the Kosovo War, Serbia kept Belgrade-controlled state structures and institutions in Serb-majority parts of Kosovo; these structures were labelled 'parallel' as they were in breach of the UN's Security Council Resolution 1244.
} 
ethnic lines by Roma, Ashkali, and Egyptians), widespread corruption, organized crime, and failure to secure the rule of law and basic human rights (Balkan Insight, 3 December 2014). A 2015 report by Freedom House (2015) on democracy in transition societies gave Kosovo the lowest possible category, as a 'semi-consolidated authoritarian regime'.

Critical perspectives have argued that, since the late 1990s, UNMIK and the wider international community have pursued a 'liberal-realist' strategy of development and peacebuilding in Kosovo, centred on securing peace, a free-market, neoliberal economy, electoral democracy, power balances across ethnic groups, and an inclusive civil society (Visoka \& Bolton 2011; Franks \& Richmond 2008). Four key criticisms are directed at this liberal-realist strategy. First, for some analysts, excessive economic liberalization has led to the undervaluing of privatized assets, the collapse of manufacturing industries, mass unemployment, poverty and migration (Knudsen 2013: 288-9). Second, Kosovo’s civil society has been dominated by NGOs and 'internationals', thereby disempowering local communities. Critics have advocated alternative civil society models rooted in 'strategic peacebuilding', and decentralized, bottom-up, pluralist, and emancipatory agendas (Richmond 2011; Visoka 2012). Third, the international community has been blighted by organizational and administrative failings, including the lack of a cooperative agenda for sustainable state- or peace-building, and being unable to tackle debilitating Serbian-backed parallel state structures (Visoka and Bolton 2011: 201). Fourth, the international community (and especially EULEX) has been charged with failing to tackle, or active complicity in, the 'omnipresent’ corruption across Kosovo (Belloni \& Strazzari 2014; Cappusela 2015). ${ }^{15}$

Overall, with respect to our international relations theories, realist standpoints help to account for the 'power politics' enveloping Kosovo, including Western hegemonic interests, and Serbia’s destabilizing parallel state; liberal approaches explain NATO, UNMIK and other

\footnotetext{
${ }^{15}$ See https://euobserver.com/justice/128316.
} 
morally-committed interventions by international institutions; and, constructivist perspectives recognize the proliferation of international NGOs and other non-state actors in post-war Kosovo, along with importance of identity issues within national politics. Critical theories have greater utility in absorbing much of these insights, by both identifying and critiquing the hybrid 'liberal-realist' and neo-liberal policies implemented in Kosovo by the international community, spotlighting concerns over democracy, transparency, and human rights, and pointing towards better alternatives that empower the different publics in Kosovo at everyday level.

Kosovo as a 'Small State'

We turn now to consider briefly how Kosovo's status as a small state is confirmed by wider literature on this subject. Four key themes are relevant here. First, Kosovo fits with realist approaches to defining small states, which refer to small territorial areas and populations, and limitations in 'hard power', such as weak economic and military capabilities (Väyrynen 1971; Hey 2003: 2-3; Lee 2006: 32). The capital, Pristina, is also small, with a population of 200,000 at the 2011 Census, although informal local estimates tend to double that figure when suburbs and recent rapid growth are included. ${ }^{16}$ Kosovo's exclusion from the European Union and structural reliance on the international community reflects the view that European small state autonomy is declining vis-a-vis the influence of regional 'great powers' (Hirsh 2010). Second, Kosovo fits also with qualitative and constructivist understandings of small states which emphasize the importance of perceptions or meanings; that is, its inhabitants widely perceive Kosovo as a small or marginal entity (Hey 2003). ${ }^{17}$ Kosovo is not among

\footnotetext{
${ }^{16}$ See file:///C:/Users/psrg4/Downloads/ESTIMATION\%20of\%20Kosovo\%20population\%202011.pdf.

${ }^{17}$ Maass (2009) recognizes the diverse ways in which small states are defined, arguing that this plurality is a positive feature, enabling case studies and research designs to be flexibly developed according to context.
} 
those few small, rich nations (like Qatar or Norway) which exercise high international economic influence or 'soft power'. Third, Kosovo illustrates subtle, relational perspectives which argue that 'smallness is defined through the relation between the state and its external environment' (Steinmetz \& Wivel 2010: 6). In this sense, small states like Kosovo are defined not by the 'power that they possess' but by the 'power that they exercise', and through being 'the weak part in an asymmetrical relationship', such as within the Balkan region or wider Europe (2010: 6). Fourth, key social themes on small states include national homogeneity and identity, and significant levels of migration (particularly out-migration). Lowenthal (1987: 39) generalizes that the inhabitants of small states work to 'minimise or mitigate overt conflict' (in Sam and Jackson 2015: 322). While showing very high levels of migration and strong ethno-national homogeneity (in being overwhelmingly Albanian), Kosovo has yet to be fully confirmed as a long-term site of concerted conflict-avoidance. Houlihan and Zheng (2015) provide a wide-ranging analysis of the diverse links between small states and sport, and three observations are particularly relevant to Kosovo. First, Kosovo is among those small states whose autonomous statehood is contested, but who utilize sport to pursue independence claims and international recognition (Houlihan and Zheng 2015: 330-1). Comparable nation-states include Palestine and Taiwan, which like Kosovo are recognized by many sport federations and different UN members but not the United Nations per se. Elsewhere, the former German Democratic Republic sought to bolster international legitimacy and recognition through international sport federation membership and elite-level sporting success, particularly in the Olympic Games. Second, Houlihan and Zheng (2015) identify various sport-focused strategies employed by small states, two of which are partly applicable to Kosovo: isomorphism/imitation, which involves 'adopting the sporting interests of a sports power or a cluster of sports powers', and camp follower, which entails 'ingratiating themselves with major states or with major international sport 
organizations' (2015: 335). These categories may be adapted for Kosovo, where the adoption and spread of sports occurred long before claims to national sovereignty were pursued, and where there were other important motives for involvement in international sport organizations, notably escaping the sense of exclusion from international sport participation and wider society. Third, Houlihan and Zheng (2015: 341) note that the study of small states centres particularly on the area of 'sport for development and peace' (SDP), thereby presenting these societies 'as passive objects rather than active, or potentially active, subjects in the policy process'. Several international NGOs undertake SDP work in Kosovo although, as we shall see, and in marked contrast to some of the criticism that is directed towards the international community on the disempowerment of citizens, these agencies do seek the active participation and empowerment of local and national groups. Overall, these three insights are particularly useful for understanding sport in the small state of Kosovo, as we explain below, alongside other issues centred on sport development.

\section{Sport in Kosovo: The Politics of Development, Recognition, and National Division}

Following the end of the Yugoslav civil war, Kosovo’s sport policies have centred on building up the national sport system, developing infrastructure (notably building facilities, and training coaches and athletes), securing international recognition, working with the international community in all of these areas as well as in using sport to promote wider social development and peace-building across different ethno-national communities. ${ }^{18}$ The Kosovo Olympic Committee had initially been created underground in 1992, at a time when Serbian domination was met by a policy of 'passive resistance' from the Albanian population and by the creation of a parallel state that was outside the control of Belgrade. After the Kosovo

\footnotetext{
${ }^{18}$ Interviews with Tereza (state sport official) and Jorgji (Kosovo Olympic committee official).
} 
War, the national Olympic Committee surfaced and, following a long period of continuous lobbying, succeeded in gaining IOC membership in 2014.

At state level, the Kosovo sport system is headed by the Department of Sport, located within the Ministry of Culture, Youth and Sports. Its annual budget in 2015 was a modest $€ 10$ million, although a new five-year plan for sport was due to raise that figure to nearer $€ 15$ million. ${ }^{19}$ As a small nation-state with a small capital city, Kosovo enables strong levels of social capital and reciprocity to be established across government sport units, sport federations, NGOs, and international donors (such as national embassies); assisting this process, the government and many sport federations hold offices in the House of Sport building in central Pristina. The dark side of this social capital was highlighted to us by several sport and NGO officials who criticized, in their view, the 'purely political' appointment of one politician to a key leadership role within their area, arguing that this individual lacked basic knowledge and experience, and failed to engage with the main stakeholders in this field.

While team sports such as football, basketball and handball are most popular, Kosovo excels on the international stage in individual sports, notably combat ones such as judo, taekwondo, boxing and wrestling, as well as archery, shooting and swimming. A leading sport journalist attributed this bias to issues of funding and the challenges of international sports competition for a small nation-state:

In team sports it costs a lot to be successful, you have to invest a lot, in individual sports there is a small amount of money but we can do a lot of things with it. That's why being a small country, not able to invest a lot in sports, knowing that the ministry of sports can’t cover all expenses for all federations, they make a strategy to be

\footnotetext{
${ }^{19}$ Interview with Edon (government sports official).
} 
focused and be successful... It's a good idea having all of us dream of having a football team in the World Cup, but it’s quite impossible, the challenges are very high. So being part of the boxing World Cup or judo World Cup is much easier.

(Roman, national sport journalist)

There is a striking prominence of women among top athletes, sport leaders and officials. Kosovo's most successful international athlete is the judo world champion, Majlinda Kelmendi. In the wider sport system, there is the widely respected Aferdita Fazlija, former football federation Vice-President and subsequent Deputy Director of the Kosovo Department of Sport; Elvira Dushku, journalist and chair of the OESK (Independent Organization of Sport Education in Kosovo); Sanije Krasniqi, referee, coach, and volunteer in diverse sport organizations; and, within the international community, consistent support came from Anne Meskanen, former Head of the Finnish Embassy in Kosovo and a strong personal advocate and donor for sport for development work. Notably, Finland's involvement in sport projects was closely tied to a strongly emancipatory position on Kosovo’s development, centred on rule of law, gender empowerment and human rights.

Kosovo's sport officials tend to highlight three major challenges that need to be confronted. First, they routinely refer to the real problems of reconstruction and the lack of proper sports infrastructure notably in facilities and training. During our research, the Department of Sport reported that Kosovo had twelve specific sport halls, eight of which dated from the Yugoslav period and required reconstruction to meet international sport standards; the Department envisaged the long-term construction of a further ten halls. ${ }^{20}$ Grassroots sport clubs often lack sufficient space to organize football, basketball, volleyball and other team sports. Several of our national and international interviewees also criticized the Kosovo government

${ }^{20}$ Interview with Arber, Kosovo government sports official. 
for failing to divert more funds into education and sport facilities, while spending heavily on large contracts with construction companies, particularly to build roads.

Furthermore, sports officials note the long-term shortfall in sustainable, detailed sport strategies and coaching resources to develop talented young athletes, with some arguing that too much focus and public funding was directed until recently into pursuing international recognition:

The moment that we enter competitions for 14-16 year olds, that's the fatal age for our sportsmen and women. The reason is that in sports we don't have pedagogy, we don't have psychologists or coaches that can work with this young generation. And the conditions of infrastructure don't allow us to produce good athletes with expectations... For fifteen years after the war, the sector of sport was mainly engaged in internationalization, and we didn't have projects for the young generation. Mainly, the budget that federations had was used only for lobbying. We didn’t have projects for the young generation, as we didn't have sustainable budgets. We didn't have experts who would work with a program or a project for four years, we had mostly projects for three months, one month, six months.

(Tereza, State Sport Official)

Demographic and socio-economic factors place further, underlying pressures on the sport system, with the need for public facilities to be secured to meet the exercise requirements for this young and relatively poor population. Some of the shortfall has been filled by the Western international community, notably through USAID, and German, Swedish, Norwegian and other national sports federations and development agencies, which have assisted, for example, with the training of coaches. Such international support varies between liberal-realist approaches that are largely pragmatic in focus, and more critical approaches 
that engage with diverse non-state actors to have emancipatory social impacts for marginalized groups. One example of the latter approach is provided by Handikos - a national NGO in existence since 1993, which promotes the rights and quality of life of disabled people, including in sport participation - which has received support from USAID, the EU Office in Kosovo, Save the Children, and the Finnish state.

Second, sport officials refer regularly to the long-term, largely successful but still incomplete struggle for full international recognition. From a liberal and constructivist standpoint, we might underline here how the cultural field of sport has constituted an important pragmatic domain for advancing Kosovo’s national recognition, beginning long before the 2008 declaration of independence. The International Table Tennis Federation was first to grant full membership to Kosovo in 2003 followed since by many other global governing bodies, such as in weightlifting, softball, water sports, judo, handball, and basketball. The big breakthrough came with full IOC membership, and one national Olympic committee official speculated on the IOC's motives, that Kosovo's membership could promote cross-community cohesion: "Now they are recognizing us, it will help us... Thomas Bach saw the perspective that everyone will be integrated now through sport, so maybe one of the reasons for this vision was, if they [the inhabitants of Kosovo] are all integrated in sport they will be integrated in social life” (Jorgji, KOC official).

As noted, the major hold-up on international recognition was in football, with the respective European and global governing bodies, UEFA and FIFA. UEFA's initial position had been that membership was only open to existing UN members. Ilir, a Kosovo sport official, commented that this position had left Kosovo in a 'vicious circle', of mutually reinforced non-recognition or exclusion in sport and wider politics. Besim, a sport journalist, pointed to the power politics within the United Nations, and thus in international sport when critiquing the sport governing bodies' position that sport should stay out of politics: 'You see the motto 
of UEFA and FIFA, that they are about sport and not politics, but each of them ask us to be part of the United Nations, and that is a political organization.' A strong 'small-state' selfperception is evidenced here, rooted in a sense of struggling to challenge the entrenched positions of greater powers such as Serbia, Russia, and Spain that oppose Kosovo's recognition.

The long-term marginality of Kosovo with regard to much international sport contributed significantly to the relative 'underdevelopment' and transnational disconnection of the nation’s sporting infrastructure. It has reinforced the societal experience of living in a national 'ghetto', where entry into 'real' international relations is deeply problematic, while reflecting more broadly how processes of globalization may serve to disconnect particular peoples and nations from social fields that otherwise feature extensive transnational interconnectedness. A material consequence of this is that Kosovo's sport federations were unable to access sport development funds, prize monies or protective payments that are otherwise available from international governing bodies. As Veton, a football official, estimated to us:

If you get recognition, you will achieve fees from UEFA, from FIFA, [FIFA] Goal project money, [UEFA] Hat-trick project money, for youth football, for women's football, from television rights to different competitions. For example, for a four-year period in Europe you could get maybe 3.5 million Euros; and about 1 million to 1.5 million Euros for women's football, for referees, for further projects.

'Human development' is further undermined by Kosovo's non-membership of the European Union. Several of our interviewees pointed to the cases of highly talented youth athletes notably a brilliant young women football player - who struggled to advance their skills by joining European sport teams or clubs due to visa restrictions; and, also to many prospective 
coaches, physical education teachers, and sport scientists who lacked the finances or freedom of movement to undertake further or higher education outside of Kosovo.

Third, Kosovo’s largely Albanian sports officials highlighted the challenges of symbolic identification and effective integration of Serbian communities within sport and the wider society. From theoretical perspectives, these observations pointed to the realist difficulties of overcoming power politics in the region, and the potential limitations of liberal-constructivist approaches, in using sport and other non-state fields to bridge the divide. Reflecting the influence of the Serbian parallel state, Serbian sport clubs in Kosovo affiliate to Serbian sport federations and compete in Serbian tournaments rather than in the Kosovar sport system. In the past, the occasional Serbian club that engaged with Kosovo’s sport system has been pressed by local groups to cut these links. For example, when the Serbian Bambi basketball team from North Kosovo played fixtures in Kosovo’s men’s Super League, the coach and players 'were labelled as traitors, they had a lot of pressure, so they dissolved' the club, as Janko, a Serbian NGO official, informed us. The coach reported receiving death threats, his business interests suffered as local municipalities refused him contracts, while parents did not allow their children to participate in cross-community activities. ${ }^{21}$

Kosovo’s non-recognition by some international sport bodies may have served indirectly to reinforce the Serbia-backed parallel state. Gezim, a leading Kosovo sport official, reported the comments of a Serbian colleague, whose sport clubs were part of Serbia’s sports system:

He said we don't want to be integrated into the Kosovo sport system ... If we are integrated in the Kosovo national federations and they are not integrated in international federations, we can’t be part of international games... He said we will

\footnotetext{
${ }^{21}$ See http://cables.mrkva.eu/cable.php?id=78684.
} 
be integrated in the national federations of Serbia because we can be part of the international federations; if Kosovo is part of international federations we would integrate into Kosovo’s national federations.

Opportunities arise to promote international legitimacy when Kosovo competes in international sports in host nations that otherwise do not recognize Kosovo’s independence. For example, at the 2016 European judo championships, the Russian hosts had initially refused to recognize the national status of Kosovo’s Majlinda Kelmendi. This stance was reversed following the intervention of the International Judo Federation's President so that, when Kelmendi took gold, at the medal ceremony, the Kosovan and Russian flags were raised together while soldiers saluted below. However, complications in recognition can arise away from the centre-stage of sport: for example, Kosovar sports journalists reported that they had been unable to obtain visas to enter Ukraine in order to cover a handball tournament, as the host nation had not formally recognized Kosovo, although the Kosovo national team was actually competing in the event.

Overall, the politics of the sport system in Kosovo are defined primarily by issues of development (such as in terms of facilities, coaching and strategy), which have been partly supported by liberal-realist and more critical strategies of the international community; the liberalist pursuit of international recognition through sport; and, the realist and liberalconstructivist challenge of divided national relations with Serbia, particularly the operation of parallel state structures in sport and the wider society. These issues connect closely to cultural political issues and challenges within sport in Kosovo to which we now turn.

\section{Sport in Kosovo: Cultural Political Issues and Challenges}


In this section, our focus switches from the largely ‘top-down' field of sport politics and policy that engages governmental organizations, to examine the relatively more 'bottom-up' realm of cultural politics that involves civil society movements, organizations and actors. Three key cultural political issues in sport in Kosovo are highlighted here. From a liberalconstructivist and critical standpoint, these issues centre on the expression and negotiation of ethno-national differences within sport and the wider society.

First, strong transnationalized identifications occur in different communities, which are foregrounded by Kosovo's ethno-national differences and divisions, history of extensive migration, and the disputed status of the nation-state. Different communities in Kosovo express strong pride and support for athletes and teams that compete under Albanian and Serbian national flags, most obviously illustrated in football during the qualifying fixtures for Euro 2016. Due to Kosovo’s non-recognition in particular sports, many leading AlbanianKosovar athletes have represented Albania: for example, Lorik Cana, Etrit Berisha, and Ermir Lenjani in football, and Kelmendi in judo. Albanian Kosovars also celebrate other elite football players, such as Xherdan Shaqiri and Granit Xhaka, who represent Switzerland, and Adnan Januzaj, representing Belgium, with close personal ties to Kosovo. In women’s football, Fatmire Alushi of Paris Saint-Germain represents Germany, was German player of the year in 2011 and was placed third in FIFA's Ballon d’Or in 2010; and, Kosovare Asllani, whose parents are Kosovar, currently plays for Manchester City and the Swedish national team (Krasniqi 2013a). Reflecting the large diaspora across Europe, Kosovo’s national football team squad features players raised in Switzerland, Germany, Norway, and Sweden. At the same time, the Serbian population in Kosovo directs strong support towards Serbian athletes and national sport teams. In football, Milos Krasic, born in North Mitrovica, was a regular Serbian international from 2006 to 2011. Most famously, Serbians in Kosovo claim the tennis champion, Novak Djokovic, as one of their own, as his family hailed from North 
Kosovo. Djokovic reciprocated these affinities in political nationalist terms: after winning the Australian Open in 2008, he stated, 'We are prepared to defend what is rightfully ours. Kosovo is Serbia., 22

Second, in liberal-constructivist terms, football and other sports may be significant symbolic fields of conflict, for the reactivation of memories of war, and the airing of contested claims over sovereignty and autonomy. Some municipalities have sport facilities that symbolically commemorate the war dead on specific sides. For example, the Olympic Stadium in Mitrovica is named after a 'Hero of Kosovo', Adem Jashari, a founding figure in the Kosovo Liberation Army, who was killed along with 57 family members by Serbian forces in $1998 .{ }^{23}$

These conflicts may spill over into real power politics at nation-state levels. The most spectacular event in recent years occurred at the Euro 2016 Serbia-Albania football fixture in Belgrade in October 2014. Several incidents of disorder occurred before and early in the fixture, including home fans burning the NATO flag and throwing missiles onto the pitch. As half-time approached, a small, remote-controlled drone helicopter, carrying a Greater Albania flag emblazoned with the words 'autochthonous' and the images of two Albanian national heroes, was directed into the stadium and glided over the pitch. A Serbian player pulled down the drone, and the two sets of players became embroiled in a melee over the flag, leading to fighting, a pitch invasion by supporters, and abandonment of the match. UEFA awarded the fixture as a walkover to Serbia, with a 3-0 score, but the decision was reversed by the Court of Arbitration for Sport which allocated the game to Albania by the same score. ${ }^{24}$ A lively slanging match subsequently ensued between Albanian and Serbian politicians; Serbians accused Albanians of provocative actions including officials wearing

\footnotetext{
${ }^{22}$ See http://www.spiegel.de/international/europe/street-fighter-artist-and-patriot-tennis-star-djokovic-is-thepride-of-new-serbia-a-790484-2.html. In football, fans of the Serb club Partizan Belgrade regularly sing 'Kosovo is the heart of Serbia' at fixtures.

${ }^{23}$ See Mills (2012) on how, in the former Yugoslavia, sports such as football have commemorated the war dead.

${ }^{24}$ See http://www.bbc.co.uk/sport/0/football/33478446.
} 
scarves bearing the emblems of the Kosovo Liberation Army, while the Albanian Prime Minister called on Serbia formally to recognize the political independence of Kosovo. Later reports revealed the drone pilot as an Albanian crane driver based in Italy, whose actions had been inspired by watching on television the burning of the Albanian flag by Serbian fans at an Italy-Serbia football fixture two years earlier (New York Times, 7 October 2015). The follow-up fixture between Albania and Serbia, played in October 2015 in Elbasan, passed off peacefully under tight security, including snipers perched on rooftops and a ban on away supporters, excepting 100 Serb and Albanian students who had been invited to attend the game together by the Albanian Prime Minister.

Third, there is a substantial and long-standing 'sport for development and peace' (SDP) movement within Kosovo’s civil society which specifically targets peace-building and improved cross-community relations. The SDP sector represents a potentially crucial way in which the relatively segregated field of sport in Kosovo has been challenged by local, national and international actors. As we explain, a kernel role has been played by international NGOs while, with respect to other external actors, key supporting contributions have followed from USAID, Council of Europe, European Union, United Nations, Austrian Development Cooperation, and various national embassies (Dutch, Finnish, German, and Norwegian) in Kosovo. However, such activity has often gone unnoticed by international relations or development analysts due to its 'peripheral' location within the 'sport' field.

Our findings point to the SDP movement's strong liberal-constructivist and critical dimensions within Kosovo. The movement emphasizes engaging and empowering local people while promoting specific critical norms and principles, such as education, equality across genders, ethnic groups and for people with disabilities, and improved crosscommunity understanding. The most prominent international SDP NGOs are 'Play International' (PI), previously known as Sport Sans Frontières) from France, and present in 
Kosovo since 2002, and the Danish 'Open Fun Football Schools’ (OFFS), active there since $2005 .^{25}$ While both are offshoots of external organizations and are thus classified as 'international', these NGOs may arguably be classified as 'local' or 'national' on the basis of their long-term local presence, use of local volunteers, or high levels of autonomy from their 'parent' entity.

The two NGOs have different strategies: PI runs multi-game activities for children across Kosovo throughout the year, while OFFS runs large-scale football events for children mainly during the summer. ${ }^{26}$ Overall, both NGOs have stronger, more inclusive relationships with local and national civil society than has otherwise been identified by some critics of the wider international community in Kosovo. Both rely heavily on local coaches or volunteers to undertake sport activities, while PI also funds local and national NGOs to implement specific projects. At the invitation of PI, we attended one weekend training event for local coaches, and a seminar at which local and national organizations were invited to bid for financial and other support for their SDP projects. Other NGOs conducting sport-related work include Aktiv, based in the Serbian North Mitrovica area in North Kosovo, which has for example undertaken basketball programmes with young people from divided communities. SDP activities in Kosovo are strongly assisted through the substantial social capital and forms of resource support that may be provided by local and national political and sport authorities, and by international actors.

Research in Kosovo encountered many positive testimonies from volunteers and participants on the personal and group impacts of these sport interventions. Kaltrina, a young Albanian programme leader whose father was killed in the civil war, commented on how sport practice was perceived to break down ethno-national barriers:

\footnotetext{
${ }^{25}$ A further, early NGO in this field was 'Spirit of Soccer'.

${ }^{26}$ On OFFS in Kosovo, see Krasniqi (2013b).
} 
If you want to go to play football, and you are Serbian, the translator is Roma, and I am Albanian, we all play together. When I start to play I don't want to know who you are or which community you are from, I want just to win, so I’ll pass the ball. My intention is to win, not to ask who you are or if I don't want to play with you. With SSF we can do this, but we need more attention from the institutions of Kosovo.

Some NGO officials indicated that an important by-product of SDP activities involves harnessing and strengthening civic activism and social engagement in Kosovo, particularly among the young. As Valerie (NGO official) commented:

What is extremely interesting is the possible improvement of youth activism here... It's very normal to have high school students who go in NGOs, and they are socially active in their community, which I think in Europe is decreasing. Here the population of Kosovo is young in general and they immediately get the motivation and willingness to fill their time in this way and to promote something they believe in for their community.

SDP initiatives in Kosovo face several political and other challenges, three of which are noted here. First, sustainability challenges concern maintaining political, financial and organizational resources and support. One NGO reported that changes in political leadership at one municipality had resulted in the withdrawal of low-cost access to sport facilities for cross-community events. Elsewhere, sport officials, volunteers and coaches complained that the international leadership of another NGO had decided to prioritize spending in other nations, resulting in the halving of their national budget. Such immediate sustainability challenges tend to be dealt with through practical action on the ground, such as reducing the scale of events. 
Second, one critical argument points to the limits of liberal-constructivist approaches in only using brief sport or other cultural activities to deal with deep-rooted social divisions. As Arben, an official at a leading national NGO, argued:

You can have sports as much as you want, you play with your Albanian friends for five years at school, say, and in $6^{\text {th }}$ grade when you open a book, your friend is reading stuff about 'gypsies'. So five years of sports activities will fall down after they read those lines... One sport activity won't change the situation. I feel that is not enough; there is hate built in their hearts, with Serbs and Albanians...Unless something long term, sustainable, and structured is happening in all mechanisms in the schools, in the families, on television, in books, then there is not going to be change.

Third, from a critical standpoint, the greatest challenge faced by SDP agencies involves the micro-macro divide, in terms of upscaling their impacts at everyday level in order to influence the larger political and societal levels where major conflicts are played out. Several NGO officials commented to us that heavily mediated international flashpoints, such as the Serbia-Albania football match, could rapidly unravel much of their grassroots work. Several interviewees advanced further, critical observations on the micro-macro challenges of effecting positive social change: on one hand, progressive, macro, legal-political structures may be put in place by the Kosovo state, for example on constitutional standards, legal protocols, and formal political statements against corruption and avowing the rights of minority groups; and, on the other hand, there are the more negative, micro, everyday experiences of sociocultural and political life in Kosovo, reflected in how these standards and protocols are ignored or bypassed, corrupt activities continue, and minority groups endure routine discrimination and marginalization in sport and beyond. 
Overall, the cultural political position of sport in Kosovo with respect to cross-community relations is double-edged. The SDP sector represents the most substantial sporting field for pursuing better relations between Kosovo’s different communities, with significant support from international organizations; the sector appears at its strongest when adopting liberalconstructivist and critical approaches. Yet, in liberal-realist terms, sport continues to be a cultural field for strong ethno-national identifications, and potential flashpoints in which long-standing tensions and enmities are sparked and played out; moreover, critical standpoints understandably point to the need for SDP's work and messages to receive greater support from other major social institutions.

\section{Concluding Comments}

This study of sport and politics in Kosovo highlights several distinctive themes and issues on the sport-society nexus within contested states. First, in broad terms, Kosovo registers the complex reciprocity of sport-society interrelations within contested states, notably in how sport is harnessed to advance particular political interests (such as international recognition, Kosovo’s independence, and Serbian claims to the territory of Kosovo), and in how the nation's weak political-economy has direct impacts on the condition of sport. Second, in the post-conflict context, Kosovo offers a unique insight into the specific issues of managing international recognition, ethno-national divisions, and parallel state structures within and through sport. Third, tensions between micro-level and macro-level relations are spotlighted, such as in how the pursuit of international recognition may distract from grassroots sport strategies; or, how strong on-the-ground work within the SDP sector may encounter wider difficulties or challenges, such as through deeper societal divisions, international flashpoints, or political failings. Fourth, sport in Kosovo points to how the struggle for international 
recognition is tied to forms of connection and disconnection, and development and underdevelopment within the international context. Fifth, while we have been restricted by space pressures from delving more deeply into this issue, Kosovo does offer a fascinating case-study for the selective application and integration of different international relations paradigms. From this, and sixth, in other contexts, some scholars have very reasonably argued that Western institutions and interests have pursued 'liberal-realist' strategies in Kosovo; others have argued that, in the field of SDP, small states tend to be treated as passive objects for Western intervention. In some contrast to these arguments, we found that international SDP agencies have pursued more 'liberal-constructivist' and critical strategies in Kosovo, by promoting inclusive, empowering and transformative relations with local communities.

The Kosovo case raises deeper questions on whether sport reflects, exacerbates or ameliorates broader political and social tensions. Arguably, Kosovo is mainly a study in reflection as, like the wider polity and society, the sport system harbours conflicts over national independence, struggles for international recognition, conflicting or competing national identities and symbols, weak development and infrastructure, major financial challenges, and parallel state structures. The exacerbation of tensions is most evidenced in nationalist flashpoints at competitive sport events. Amelioration occurs most obviously through the SDP sector, but also more broadly when sport enables non-violent contact between, and forms of social integration across, the different communities.

A further question concerns whether Kosovo points to discernible trends in the relationship between sport and regional politics. One argument here is that, despite flashpoint moments, sport provides for the potential normalization of relations in the Balkans, by bringing postconflict states into an important contact-space within international society. In addition, sport 
has been a key field for the promotion of Kosovo’s recognition by international society, including Serbia and its allies. Such recognition is pivotal for the greater stabilization and wider integration of the Western Balkans, notably for any future EU membership of Serbia and most likely Kosovo.

Looking ahead, sport in Kosovo will be shaped in the medium and long term by three interrelated factors. First, from a critical theoretical perspective, we must recognize the crucial importance of deeper structural transformations within Kosovo. Substantial political, legal and economic development is essential for increasing employment, enhancing reconstruction, reducing migration, and building communities - all of which will feed into the making of a stronger, more resilient sport system.

Second, in liberal-realist terms, further international integration of Kosovo within and beyond sport will be predicated in part on the stabilization of relations with Serbia (including formal recognition), and by greater ties to the European Union. Such integration would be expected to involve the removal of parallel state structures in Kosovo, the lifting of restrictions on the movement of Kosovar athletes across Europe, and the greater development of sport facilities and infrastructure.

Third, we spoke to several highly-experienced officials at international agencies who envisioned the downsizing of their activities, and questioned whether Kosovo’s government and civil associations would be able to step in to fill the resulting void. Certainly, international SDP NGOs have worked assiduously to develop local capacity. Yet the sustainability of these and other sport initiatives would be enhanced through their continued resourcing by these external agencies. That continued international involvement might remain at least until Kosovo becomes more integrated within international society and, 
ideally through more liberal-constructivist and emancipatory policies, is equipped to strengthen its polity, economy and civil society.

\section{References}

Barnett, M.N. and M. Finnemore (2004) Rules for the World: International Organizations in Global Politics, Ithaca: Cornell University Press.

Belloni \& Strazzari (2011) 'Corruption in Post-Conflict Bosnia-Herzegovina and Kosovo: A Deal Among Friends’, Third World Quarterly, 35(5): 855-871.

Capussela, A.L. (2015) State-Building in Kosovo: Democracy, Corruption and the EU in the Balkans, New York: Tauris.

Franks, J. \& O.P. Richmond (2008) ‘Co-Opting Liberal Peacebuilding: Untying the Gordian Knot in Kosovo’, Cooperation and Conflict, 43(1): 81-103.

Freedom House (2015) 'Nations in Transit 2015: Democracy on the Defensive in Europe and Eurasia', Washington: Freedom House

Gilpin, R. (1987) The Political Economy of International Relations, Princeton: Princeton University Press.

Heraclides, A. (1997) ‘The Kosovo Conflict and its Resolution: In Pursuit of Ariadne’s Thread', Security Dialogue, 28(3): 317-331.

Hey, J.A.K. (2003) ‘Introducing Small State Foreign Policy’, in J.A.K. Hey (ed.) Small States in World Politics, Boulder: Lynne Rienner. 
Hirsch, M. (2010) 'Preface: About the Resilience of Small States', in R. Steinmetz \& A. Wivel (eds) Small States in Europe, Aldershot: Ashgate.

Houlihan, B. and J. Zheng (2015) 'Small States: Sport and Politics at the Margin’, International Journal of Sport Policy and Politics, 7(3): 329-344.

Keck, M.E. and K. Sikkink (1998) Activists beyond Borders: Advocacy Networks in International Politics, Ithaca: Cornell University Press.

Keohane, R. (2012) 'Twenty Years of Institutional Liberalism’, International Relations, 26(2): 125-138.

Ker-Lindsay, J. (2012) Kosovo: The Path to Contested Statehood in the Balkans, London: Tauris.

Knudsen, R.A. (2013) 'Privatization in Kosovo: “Liberal Peace” in Practice’, Journal of Intervention and Statebuilding, 7(3): 287-307.

Kosovo 2.0 (2015) Sports, 8/Spring.

Krasniqi, S. (2013a) 'Female Football in Kosovo’, paper to the FREE Conference, University of Copenhagen, June.

Krasniqi, S. (2013b) Sport and Peace Building in Post-Conflict Societies: The Role of Open Fun Football Schools in Kosovo, unpublished Masters thesis, University of Pristina, Kosovo. Lee, M. (2006) How Do Small States Affect the Future Development of the EU?, New York: Nova.

Linklater, A. (2007) Critical Theory and World Politics: Citizenship, Sovereignty and Humanity, London: Routledge. 
Lowenthal, L. (1987) ‘Social Features’, in C. Clarke and T. Payne (eds) Politics, Security and Development in Small States, London: Allen \& Unwin.

Maass, M. (2009) 'The Elusive Definition of the Small State’, International Politics, 46: 6583.

Mills, R. (2012) ‘Commemorating a Disputed Past: Football Club and Supporters’ Group War Memorials in the Former Yugoslavia’, History, 97: 540-577.

Petersen, R.D. (2011) Western Intervention in the Balkans, Cambridge: Cambridge University Press.

Richmond, O.P. (2011) A Post-Liberal Peace, London: Routledge.

Roach, S.C. (ed.) (2007) Critical Theory and International Relations: A Reader, London: Routledge.

Sam, M. \& S. Jackson (2015) 'Sport and Small States', International Journal of Sport Policy and Politics, 7(3): 319-327.

Steinmetz, R. \& A. Wivel (2010) 'Introduction’, in R. Steinmetz \& A. Wivel (eds) Small States in Europe, Aldershot: Ashgate.

Sterland, B. (2006) Civil Society Capacity-Building in Post-Conflict Societies: The Experience of Bosnia and Herzegovina and Kosovo, Praxis Paper Number 9, Oxford: Intrac.

Vayrynen, R. (1971) 'On the Definition and Measurement of Small Power Status', Cooperation and Conflict, 6(1): 91-102.

Visoka, G. (2012) ‘The “Kafkaesque Accountability” of International Governance in Kosovo’, Journal of Intervention and Statebuilding, 6(2): 189-212. 
Visoka, G. and G. Bolton (2011) 'The Complex Nature and Implications of International Engagement after Kosovo's Independence’, Civil Wars, 13(2): 189-214.

Visoka, G. and J. Doyle (2015) 'Neo-Functional Peace: The European Union Way of Resolving Conflicts', Journal of Common Market Studies, available at: http://onlinelibrary.wiley.com/doi/10.1111/jcms.12342/epdf.

Wight, M. (1946) Power Politics, London: Royal Institute of International Affairs. 